This pre-print manuscript "Spatio-temporal trends of nitrogen deposition and climate effects on Sphagnum productivity in European peatlands" was subsequently accepted by Environmental Pollution.

This version of the manuscript has not been peer-reviewed.

Published with permission from Elsevier.

Statement from the publisher: "NOTICE: this is the author's version of a work that was accepted for publication in $<$ Environmental Pollution $>$. Changes resulting from the publishing process, such as peer review, editing, corrections, structural formatting, and other quality control mechanisms may not be reflected in this document. Changes may have been made to this work since it was submitted for publication. A definitive version was subsequently published in ENVIRONMENTAL POLLUTION, [VOL\#187, (April 2014)] DOI\#10.1016/j.envpol.2013.12.023 *

Epsilon Open Archive http://epsilon.slu.se 


\section{Spatio-temporal trends of nitrogen deposition and climate effects on Sphagnum productivity in European peatlands}

Gustaf Granath $^{1,2}$, Juul Limpens ${ }^{3}$, Maximilian Posch ${ }^{4}$, Sander Mücher ${ }^{5}$, Wim de Vries ${ }^{5,6}$

*Corresponding author: Gustaf.Granath@gmail.com

Tel: + 1905 525-9140 ext. 20437

${ }^{1}$ School of Geography and Earth Sciences,

McMaster University, 1280 Main Street West,

Hamilton, ON, L8S 4K1, Canada

${ }^{2}$ Department of Aquatic Sciences and Assessment, Swedish University of Agricultural Sciences, Box 7050, SE-75007 Uppsala, Sweden

${ }^{3}$ Nature Conservation and Plant Ecology Group, Wageningen University, PO Box 47, Wageningen, The Netherlands

Email: juul.limpens@wur.nl

${ }^{4}$ Coordination Centre for Effects (CCE), RIVM, PO Box 1, 3720 BA Bilthoven, The

Netherlands

Email: max.posch@rivm.nl

${ }^{5}$ Alterra, Wageningen University and Research Centre (WUR), PO Box 47, 6700 AA

Wageningen, The Netherlands

Email: sander.mucher@wur.nl

${ }^{6}$ Environmental Systems Analysis Group, Wageningen University, PO Box 47, 6700 AA

Wageningen, The Netherlands

Email: wim.devries@wur.nl

Running title: Trends of N deposition effects on Sphagnum

Tables: 2

Figures: 3 
49

50

51

52

53

\section{Abstract}

To quantify potential nitrogen $(\mathrm{N})$ deposition impacts on peatland carbon (C) uptake, we explored temporal and spatial trends in $\mathrm{N}$ deposition and climate impacts on the production of the key peat forming functional group (Sphagnum mosses) across European peatlands for the period1900 - 2050. Using a modelling approach we estimated that between 1900-1950 N deposition impacts remained limited irrespective of geographical position. Between 1950$2000 \mathrm{~N}$ deposition depressed production between $0-25 \%$ relative to 1900 , particularly in temperate regions. Future scenarios indicate this trend will continue and become more pronounced with climate warming. At the European scale, the consequences for Sphagnum net C-uptake remained small relative to 1900 due to the low peatland cover in high-N areas. The predicted impacts of likely changes in N deposition on Sphagnum productivity appeared to be less than those of climate. Nevertheless, current critical loads for peatlands are likely to hold under a future climate.

Keywords: air pollution, carbon balance, critical load, ecosystem change, peat mosses

Capsule: Temperate Sphagnum peatlands are vulnerable to current and future N deposition and current critical loads for peatlands are likely to hold under a future climate.

\section{Introduction}

Deposition of reactive nitrogen $(\mathrm{N})$ has increased steadily in many parts of the world since the industrial revolution (Galloway et al. 2003). At present $\mathrm{N}$ deposition levels are either stabilizing at a high level (Europe) or continue to increase in other parts of the world (de Vries $\&$ Posch 2011). N effects are numerous, ranging from biodiversity loss to increased leaching of nitrate to aquifers and lakes (e.g. Bergström \& Jansson 2006). To improve risk assessments and support policy decisions, critical $\mathrm{N}$ deposition loads have been defined for many ecosystems (Bobbink \& Hettelingh 2011), including Sphagnum-dominated peatlands. These extremely nutrient-poor ecosystems are among those most sensitive to $\mathrm{N}$ enrichment, and show changes in species composition above $\mathrm{N}$ deposition levels of 5-10 $\mathrm{kg} \mathrm{ha}^{-1} \mathrm{yr}^{-1}$ (Bobbink \& Hettelingh 2010). Recent work suggests that N-impacts on Sphagnum depends on climatic factors (Heijmans et al. 2008; Limpens et al. 2011), implying critical loads may vary across geographical gradients and may change with climate warming. Our study is the first attempt 
to explore the spatial distribution of $\mathrm{N}$ effects on Sphagnum production in peatlands for past, present and future.

Sphagnum-dominated peatlands cover large areas of the boreal-temperate zone and store a substantial amount of the global soil carbon (C) pool (Rydin \& Jeglum 2013). Peat mosses (genus Sphagnum) play a key role in these ecosystems as they efficiently engineer an environment that facilitates their own growth while being hostile to vascular plants (van Breemen 1995). Their unique properties are both directly and indirectly responsible for the long-term C sequestration of northern peatlands. Sphagnum directly affects C-sequestration by producing litter that decays at a slower rate than vascular plants (Freeman et al. 2001), thus forming a much greater proportion of the peat than expected from their primary production (Wallén, 1992),. Sphagnum litter/peat is also responsible for the wet and acidic environment that suppresses decay, thus indirectly facilitating long-term C-sequestration. Thus, Sphagnum production and abundance are of vital importance for the functioning and $\mathrm{C}$ accumulation of Sphagnum-peatlands (Johnson \& Damman 1993). The proportion of annual Sphagnum production that is eventually integrated into long-term $\mathrm{C}$ storage (peat accumulation) varies between 0-10\%, depending on environmental conditions (Rydin \& Jeglum 2013). This can translate into an average carbon accumulation of circa $20 \mathrm{~g} \mathrm{C} \mathrm{m}^{-2} \mathrm{yr}^{-1}$ (Roulet et al. 2007). Although peatland habitats are usually resilient to environmental change (Belyea \& Baird 2006), nutrient alterations can lead to drastic changes in the composition of the vegetation. In general vascular plants benefit from the surplus $\mathrm{N}$ and become more dominant while the growth ofpeat mosses decreases due to litter burial and shading (Berendse et al. 2001). There is also experimental evidence of more direct effects of increased $\mathrm{N}$ availability on Sphagnum performance, such as increased photosynthesis, $\mathrm{P}$ limitation and even toxicity at very high $\mathrm{N}$ levels (Granath et al. 2009, Granath et al. 2012, Limpens and Berendse 2003). Consequently, $\mathrm{N}$ deposition has been suggested as a potential threat to $\mathrm{C}$ sequestration of boreal and temperate peatlands (Gunnarsson et al. 2008; Dise 2009). Yet, attempts to quantify this threat are lacking. This is in sharp contrast to forest ecosystems where $\mathrm{N}$ deposition effects on $\mathrm{C}$ sequestration have been quantified at a European scale (de Vries et al. 2006; de Vries \& Posch 2011).

A modelling approach is necessary to quantify the effects of $\mathrm{N}$ deposition at a larger scale, and until recently, no model was available for Sphagnum. A recent meta-regression analysis (Limpens et al. 2011), was an important step forward in the process of understanding and 
quantifying the effect of $\mathrm{N}$ on Sphagnum growth in peatlands. Using results of $\mathrm{N}$ application experiments across the northern hemisphere, the authors identified some of the variables that may affect Sphagnum growth response to $\mathrm{N}$ deposition. This analysis resulted in a statistical model that describes the impact of $\mathrm{N}$ deposition on Sphagnum production in interaction with climatic factors. By combining this statistical model with $\mathrm{N}$ deposition and climate data for European peatlands for the past, present and future (1900-2050) we investigated, i) how N deposition has affected Sphagnum production, temporally and spatially across Europe, over the 20th century, ii) the effect of future N deposition on Sphagnum production, given future climatic and $\mathrm{N}$ deposition projections, and iii) the overall consequences for Sphagnum production and potential C-uptake at European scale.

\section{Methods and Materials}

\section{Modelling the effect of nitrogen deposition on Sphagnum}

We adapted the meta-regression model of Limpens et al (2011), further referred to as Limpens-Granath model, to model the effect of N deposition on Sphagnum productivity under different climatic conditions. Our adapted model is expressed as:

$$
\log _{\mathrm{e}}\left(P_{\text {treat }} / P_{\text {control }}\right)=\mu+a \times N_{c}+b \times N_{\text {add }}+c \times T_{j}+d \times P_{a}+C+\text { Error }
$$

where $\mu$ is the intercept, $N_{c}$ is the current mean annual $\mathrm{N}$ deposition at the site at the time of treatment, $N_{a d d}$ is the annual added $\mathrm{N}$ at treatment plots, $T_{j}$ is the mean July temperature (which is strongly correlated with mean summer temperature, June-August), $P_{a}$ is mean annual precipitation, $P_{\text {control }}$ is the Sphagnum productivity at the control plots receiving only $N_{c}$, and $P_{\text {treat }}$ is the Sphagnum productivity at the treatment plots, receiving $N_{c}+N_{a d d} . C$ and $a, b, c, d$ are regression coefficients, where $C$ also includes the effects of phosphorus application and presence of vascular plants. The Error term captures the unexplained between-experiment variation.

Adaptations to the Limpens-Granath model included the use of more recent climate and background $\mathrm{N}$ deposition data, and a further simplification of parameters and adaptation of $N_{c}$ 
and $N_{\text {add }}$ to make the model suitable for comparing $\mathrm{N}$ effects over different time periods instead of between treatments. These adaptations are discussed below.

\section{Parameterization}

The model was parameterized using the same experimental data as in Limpens et al. (2011) The most important details are given in Table S1 (sources, location, species, $\mathrm{N}$ application rate). In contrast to Limpens et al. (2011), we used more recent climate and background $\mathrm{N}$ deposition data. For the adapted model (1) we used gridded average climate data for a 10-year period encompassing the timing of the experiments based on the Climate Research Unit (CRU) data base (Mitchell et al. 2004). Furthermore, annual total background $\mathrm{N}$ deposition (i.e. wet plus dry) was used instead of only wet deposition as in Limpens et al. (2011). Most $\mathrm{N}$ application experiments were conducted in Europe and wet and dry $\mathrm{N}$ depositions for the years of the experimental duration were extracted from the European Monitoring and Evaluation Programme (EMEP MSC-W model results, http://www.emep.int/mscw/index_mscw.html). For non-European sites, N deposition was retrieved from original publications. More details on $\mathrm{N}$ deposition and climate data can be found in the methods section below. The model was fitted using a Bayesian approach in the $\mathrm{R}$ package MCMCglmm (Hadfield 2010) to more easily include parameter uncertainties in the spatial models. For parameterization, we ran the model for 140000 iterations after a burn-in of 30000 iterations, using non-informative priors. Changing the priors did not alter the results and ensures little influence of the priors on the posterior (see Limpens et al. (2011) for details on fitting hierarchical meta-regression models accounting for within-study dependence).

The Limpens-Granath model included the effect of microhabitat (moist lawn vs. dry hummocks) and an interaction between microhabitat and temperature. As the proportions of microhabitats in peatlands are not well-documented, we removed the terms involving microhabitat in the model, generalizing our predictions. In addition, the Limpens-Granath model included variables that were manipulated in the experiments: phosphorus application and presence of vascular plants (some experiments removed vascular plants). In our predictions we assumed that phosphorus was not added and vascular plants were not removed. 
To test if the adapted Limpens-Granath model would lead to a loss of predictive value, we compared both the original and adapted models using the experiment data set of Limpens et al. (2011). Our simpler model performed as well as the original model, with predictors explaining 51\% (present model) and 53\% (Limpens-Granath model) of the variation among experiment outcomes (log response ratio), respectively. Model parameters estimated for our revised model are given in Table 1.

Our model was applied on a $0.5 \times 0.5$ degree longitude-latitude grid ( 8539 grid cells with peatlands) covering Europe except for the most eastern parts where the peatland distribution is not available (Ukraine, Belarus, Moldova and Greece, see Figure 2).To make spatial predictions, we used July temperature, annual precipitation and annual $\mathrm{N}$ deposition data for each grid cell. Model uncertainty (parameter uncertainty and random variation) was incorporated by performing random draws of parameter estimates from the joint distribution of the meta-regression model. We made 5000 random draws for predicting the outcome at each grid cell and time period. From these 5000 predictions we calculated the mean and the $90 \%$ and $50 \%$ uncertainty intervals.

Including all model uncertainties gave wide uncertainty intervals. A large part of that uncertainty comes from the unexplained between-study variation (Table 1), which is mainly a result of large within-peatland variation in Sphagnum species and vascular plant cover. Since we were not interested in the within-peatland variation but rather in the aggregated response of the whole peatland to $\mathrm{N}$ deposition, we removed the uncertainty related to Sphagnum species for the uncertainty graphs. To this end we first analyzed a subset of the data used in Limpens et al. (2011) that only contains studies with more than one species (see Table S1). From this data we estimated that the species component explained about $25 \%$ of betweenstudy variation. This variation was removed when prediction intervals were created for the graphs presented in the supporting information (see figures in Appendix S1 in Supporting Information).

\section{To summarize the effect over Europe we calculated weighted means of predictions using} proportions of peatlands in each grid cell as weights. The estimation of the peatland cover is described later in the methods section. Effects on carbon uptake were calculated by assuming a mean annual Sphagnum production of $200 \mathrm{~g}$ dry matter $\mathrm{m}^{-2} \mathrm{yr}^{-1}$. This value is derived from a meta-analysis of Sphagnum production (Gunnarsson 2005) enhanced by the production rates 
observed in the control plots of the $\mathrm{N}$ addition experiments that formed the basis of our model. The $200 \mathrm{~g} \mathrm{~m}^{-2} \mathrm{yr}^{-1}$ is a representative, albeit conservative (e.g. Wieder et al. 2010), estimate of long-term production values and thus highly suitable for the 50-year time step adopted in our study. To convert the dry matter production to C-uptake we assumed a dry tissue carbon content of 50\% (Rydin \& Jeglum 2013).

\section{Modelled time periods and scenarios}

We analysed N deposition effects between 1900-1950, 1950-2000 and four different scenarios for the period 2000-2050; combining (1) two $\mathrm{N}$ deposition scenarios (current $\mathrm{N}$ deposition, using means of 2000-2010, and future N deposition, according to the Global Energy Assessment current legislation, GEA-CLE), with (2) two climate scenarios (current climate, using means of 1950-2000, and future climate, according to the A1 climate scenario). For more information on these scenarios see sub-section Nitrogen deposition 1900-2050 and Climate data 1900-2050.

\section{Modelling $N$ effects over time}

The response variable in the Limpens-Granath model was the ratio of Sphagnum productivity in treatment over control, i.e. the model predicts the change in Sphagnum productivity compared to a reference point. Consequently, to apply the Limpens-Granath model based on $\mathrm{N}$ addition experiments to field conditions, we needed to set a reference point with which to compare the effects of increasing $\mathrm{N}$ deposition. We used the year 1900 as reference point, assuming that $\mathrm{N}$ deposition at that time reflects pre-industrial times (de Vries \& Posch 2011).

$\mathrm{N}$ load in the Limpens-Granath model was divided over $\mathrm{N}$ deposition at the experimental site ( $\mathrm{N}$ current $\left.=N_{c}\right)$ and experimentally applied $\mathrm{N}\left(N_{a d d}\right)$. For our adapted model we also divided $\mathrm{N}$ deposition over the terms $N_{c}$ and $N_{a d d}$, where $N_{c}$ presented the impact of long-term historic $\mathrm{N}$ deposition, and $N_{\text {add }}$ the impact of additional $\mathrm{N}$ deposition. We used one or two allocation steps, depending on the change in $\mathrm{N}$ deposition between 1900 and 2050. If $\mathrm{N}$ deposition changed less than $0.4 \mathrm{~g} \mathrm{~m}^{-2}$ between 1900 and 2050, no reliable predictions could be made between the periods as the Limpens-Granath model assumes a minimum $N_{\text {add }}$ of $0.4 \mathrm{~g} \mathrm{~m}^{-2}$. One allocation step was used when the change in mean $\mathrm{N}$ deposition between 1900-2050 exceeded $0.4 \mathrm{~g} \mathrm{~m}^{-2} \mathrm{yr}^{-1}$. Then the $\mathrm{N}$ deposition in 1900 was allocated to $N_{c}$, and all other $\mathrm{N}$ to $N_{a d d}$. If the change in $\mathrm{N}$ deposition between 1950-2000 to 2000-2050 was higher than $0.4 \mathrm{~g} \mathrm{~m}^{-}$ 
${ }^{2} \mathrm{yr}^{-1}$ we used two allocation steps: $\mathrm{N}$ deposition in 1900 was allocated to $N_{c}$ for the period 1950 to 2000, and the average $\mathrm{N}$ deposition between 1950 and 2000 was allocated to $N_{c}$ for the period 2000-2050. In the latter case, the outcome was multiplied with the first outcome (effect 1900 to 1950-2000) to keep comparisons to 1900.

\section{Model evaluation}

The sensitivity of our model was evaluated in two ways; 1) to investigate the effect of potential uncertainty of our modelled predictors we ran the model with an uncertainty (standard deviation set to 5\% of the value) around modelled predictor values ( $\mathrm{N}$ deposition, temperature and precipitation), and, 2) to test the effect of different ways of allocating $\mathrm{N}$ deposition over $N_{c}$ and $N_{\text {add }}$. In addition, we explored an alternative model where the parameters $N_{c}$ and $N_{a d d}$ were merged into a single parameter (total $\mathrm{N}$ addition, $N_{c+a d d}$ ). The test of this alternative model was also restricted to the $0.4 \mathrm{~g} \mathrm{~m}^{-2} \mathrm{yr}^{-1}$ minimum increase since 1900.

\section{Nitrogen deposition 1900-2050}

Oxidised and reduced $\mathrm{N}$ deposition were calculated with the atmospheric transport model of EMEP/MSC-W (Simpson et al. 2012). Historic $\mathrm{NO}_{\mathrm{x}}$ and $\mathrm{NH}_{3}$ emissions were taken from Lamarque et al. (2010). Predictions for the period 2000-2050 were based on a (1) constant $\mathrm{N}$ deposition scenario, i.e. fixing $\mathrm{N}$ deposition to the current levels, here defined as the mean for the period 2000-2010, and, (2) Global Energy Assessment (GEA) current legislation scenario (GEA-CLE). The GEA-CLE deposition scenario assumes full implementation of all current and planned air pollution legislation world-wide until 2030.

\section{Climate data 1900-2050}

Historical meteorological data were taken from a high resolution European data base (Mitchell et al. 2004) that contains monthly values of temperature, precipitation and cloudiness for the years $1901-2000$ for land-based grid-cells west of $32^{\circ} \mathrm{E}$ of size $10^{\prime} \times 10^{\prime}$ (approx. $15 \mathrm{~km} \times 18 \mathrm{~km}$ in central Europe). In the simulations, 10-year averages were taken centred around 1900, 1910, .., 1990 (1900 is the average of 1901-1905; 1910 of 1906-1915 etc.) to smooth the climate pattern. For future values we used two climate scenarios: (1) constant climate after 1990 (using the average of the 1961-1990 period); (2) from 2010 onwards the A1 storyline from the Special Report on Emission Scenarios (SRES) with its related climate scenario (Nakićenović \& Swart 2000). This scenario, which is from the IPCC 
scenario family with the highest emissions, reflects a future world with globalization and rapid economic growth, low population growth, and the rapid introduction of new and more efficient technologies everywhere. The A1 scenario was chosen in this study as the most likely future scenario, considering that current $\mathrm{CO}_{2}$ emission trends exceed this most pessimistic IPCC scenario (Raupach et al. 2007). Mitchell et al. (2004) used results from the HADCM3 General Circulation Model to derive monthly meteorological data for the years 2001-2100 from this (and several other) scenario, which we again averaged over 10-year periods for use in the simulations. For the transition period, 1990-2010, data were interpolated linearly. Under the A1 climate scenario, temperatures over Europe increase by about $3 \pm 1^{\circ} \mathrm{C}$ between 1990 and 2050, whereas median precipitation hardly changes, with precipitation at southern sites decreasing and at northern sites increasing compared to 1990 (see also de Vries \& Posch 2011).

\section{Spatial distribution of peatlands in Europe}

We improved the estimation of the coverage of open Sphagnum dominated peatlands by integrating the CORINE (CO-oRdination of INformation on the Environment) land cover 2006 of the European Environmental Agency (EEA) with the Forest Map of the Joint Research Centre (JRC) of the European Commission. The CORINE land cover is derived from high resolution satellite data (e.g. Landsat-TM) by computer assisted visual interpretation in combination with ancillary data. The minimum mapping unit is 25 ha and for line elements the minimum width is $100 \mathrm{~m}$. Büttner and Maucha (2006) validated the CLC2000 and found a total reliability of CLC2000 was $87.0 \pm 0.8 \%$. The JRC Forest Cover Map is a $25 \mathrm{~m}$ spatial resolution raster Pan-European Forest / Non Forest Map with target years 2000 and 2006 derived from high resolution satellite data such as LISS III and SPOT 4/5 imagery. In the JRC forest map, forests are defined as vegetation dominated by trees, with canopy closure more than $30 \%$ and trees higher than $5 \mathrm{~m}$. For its integration with CORINE, the JRC Forest Map was resampled to a $100 \mathrm{~m}$ grid (same resolution as CORINE) using a majority filter.

From CORINE land cover we selected the land cover class 4.1.2 Peat bogs, which has been defined as: peatland consisting mainly of decomposed moss and vegetable matter which might be exploited (Bossard et al. 2000). It includes minerogenic peatlands (fed by ground water) with mosses (mostly Sphagnum), ombrogenic peatlands (fed only by precipitation and dominated by Sphagnum) such as boreal bogs, boreal bogs with reticulated structure (aapa), 
313 blanket bogs, and fossil arctic peat bogs (palsa). The integrated map of JRC forest and

314 CORINE land cover (2006), focusing on non-forested peatlands, was analysed over European sites where $\mathrm{N}$ application experiments used in the meta-analysis were performed, and over other sites where Sphagnum production had been recorded in the literature. Our combined map showed an improvement over CORINE 2006 concerning open, Sphagnum dominated peatlands.

The gridded peatland distribution map was first re-projected and then overlaid with the gridded climate/ $\mathrm{N}$ deposition map $(0.5 \times 0.5$ longitude-latitude grid) to calculate the proportion of peatland per cell. This was done using the R packages raster (Hijmans \& van Etten 2012) and rgdal (Keitt et al. 2012). All maps are shown with the EPSG:3035 projection.

\section{Results}

\section{$N$ deposition trend and peatland cover}

Estimated $\mathrm{N}$ deposition varied over time and space. At the beginning of the 1900s, N deposition was generally low, except for a region in central Europe and the southern British Isles. Between 1900 and $1950 \mathrm{~N}$ deposition increased slightly, but not more than $0.4 \mathrm{~g} \mathrm{~m}^{-2} \mathrm{yr}^{-1}$ on average over the whole period (Fig 1a). From 1950 onwards, N deposition rose quickly, reaching peak values around 1980-1990, after which it decreased slightly and levelled off to the present levels in many areas. The total change in $\mathrm{N}$ deposition exceeded $0.4 \mathrm{~g} \mathrm{~m}^{-2} \mathrm{yr}^{-1}$ in most areas (Fig 1b). Predictions for 2000-2050 under the current legislation N emission scenario (GEA-CLE) vary per region, with $\mathrm{N}$ deposition increasing or decreasing, depending on location (Fig 1c). In the constant (mean 2000-2010) scenario, most areas showed a minor decrease compared to the 1950-2000 period (not shown).

Combining CORINE land cover data and the JRC forest map, we estimated open/semi-open Sphagnum-dominated peatland cover in Europe to be10.5 million ha. About $20 \%$ of these peatlands are defined as forested. The highest cover of peatlands is found in Fennoscandia and the British Isles (Fig 2).

Spatial predictions for Sphagnum productivity 
For the period 1900-1950 we could not make reliable predictions for changes in Sphagnum productivity as the change in $\mathrm{N}$ deposition remained below $0.4 \mathrm{~g} \mathrm{~m}^{-2}$ (the minimum amount needed for modelling predictions, see Methods) for all regions. For 1950-2000, large areas of Europe did show a sufficient increase in $\mathrm{N}$ deposition for making predictions. This area includes approximately 1 million hectares of Sphagnum dominated peatlands. Over this period, our model estimated that N deposition depressed Sphagnum production between between 0 and $25 \%$ in western, central and eastern Europe (Fig 3a), but increased production in south-eastern Sweden. N deposition in parts of Ireland and northern Fennoscandia did not change enough to allow reliable predictions. When summarized over all predictions and taking peatland cover into account, the overall $\mathrm{N}$ effect on Sphagnum production, and consequently on the Sphagnum C balance of the living parts, was close to zero (Table 2).

Over 2000-2050 N deposition is predicted to depress Sphagnum production further under both the constant $\mathrm{N}$ emission scenario (using average $\mathrm{N}$ deposition of 2000-2010; Fig 3c) and the current legislation $\mathrm{N}$ emission scenario (GEA-CLE deposition scenario; Fig 3b). Without a change in climate however, predictions are similar to 1950-2000 (Fig. 3d). The strongest overall reduction of Sphagnum production occurs under the constant $\mathrm{N}$ deposition and A1 climate scenario (Table 2, Fig 3c) and the weakest is under the reduced $\mathrm{N}$ deposition and constant climate scenario (Table 2, Fig 3d). The predicted impacts of $\mathrm{N}$ deposition appeared to be less (on average 3 percentage points difference between constant and reduced $\mathrm{N}$ deposition) than those of climate change (on average 7-8 percentage points difference between constant climate and climate change according to $\mathrm{A} 1$; see table 2). The consequences of the different scenarios for $\mathrm{C}$ uptake show large spatial variation, but little-no difference when upscaled to Europe (Table 2).

\section{Model uncertainty and sensitivity}

Including all model uncertainties gave wide uncertainty intervals even when correcting for contribution of within peatland uncertainty. Hence parameter uncertainty is the largest contributor to the overall uncertainty (Supporting information, Fig. S1, S2).

When looking at the sensitivity of the model, a standard deviation of 5\% for a predictor value (e.g. an $\mathrm{N}$ deposition value of $1.0 \mathrm{~g} \mathrm{~m}^{-2} \mathrm{yr}^{-1}$ is assumed to be estimated with a standard deviation of $0.05 \mathrm{~g} \mathrm{~m}^{-2} \mathrm{yr}^{-1}$ ) did not change our predictions substantially. If we did not use 
378 allocation steps for $N_{c}$, but only one fixed $N_{c}$ ( $\mathrm{N}$ deposition in1900) for all time periods, our future predictions (2000-2050) suggested less negative effects of $\mathrm{N}$ deposition. Also, the model where $N_{c}$ and $N_{a d d}$ were merged into one parameter $\left(N_{c+a d d}\right)$ did not diverge much from our original model. In this case, however, the model produced more extreme predictions near the boundaries of model space and stronger negative effects were predicted at lower $\mathrm{N}$ deposition levels because a larger proportion of $\mathrm{N}$ deposition was allocated to $N_{c}$. The instability of this model $\left(N_{c+a d d}\right)$ makes it less useful despite its simplicity and thus the results from the two-step allocation model are the only ones presented here.

\section{Discussion}

\section{Nitrogen deposition impacts}

For the second half of the $20^{\text {th }}$ century, our model suggests that $\mathrm{N}$ deposition will depress Sphagnum production in many areas by $0-25 \%$ relative to 1900 . This reduction nearly equals the year-to-year variation due to weather conditions observed in contemporary Sphagnum production studies (e.g. Vitt 1990). These modelled trends correspond to independent field observations of peat accumulation (Gunnarsson et al. 2008), vegetation changes (Kapfer et al. 2011) and Sphagnum N concentration (Malmer \& Wallén 2005).

The N deposition impact varied spatially, with N deposition depressing Sphagnum production mostly in peatlands approximately south of $60^{\circ}$ latitude, with the exception of Eastern Sweden. North of $60^{\circ}$ latitude, changes in Sphagnum production could generally not be modelled because $\mathrm{N}$ deposition changed less than $0.4 \mathrm{~g} \mathrm{~m}^{-2} \mathrm{yr}^{-1}$ relative to 1900 . However based on our model, it is likely that $\mathrm{N}$ deposition had little effect on Sphagnum production and probably stimulated growth. Unfortunately, there are no long-term data sets on Sphagnum production that we can use for direct validation of our model results, restricting validation to comparisons of patterns observed in vegetation composition and litter production which may be viewed as indirect proxies for Sphagnum production. Below we compare our results with patterns observed in vegetation composition and litter production in bogs. Our spatial distribution of $\mathrm{N}$ deposition impacts corresponds with that observed in studies focussing on peatland vegetation composition. For example, in Southern Sweden ( $60^{\circ}$ latitude) where our model estimates a net positive effect over the $20^{\text {th }}$ century, Gunnarsson et al. (2000) found no evidence of $\mathrm{N}$-induced changes in vegetation composition, whereas in England where our 
model estimates negative effects, Chapman \& Rose (1991) reported negative effects on vegetation, notably on Sphagnum cover. Another interesting example is the peatland Store mosse in SW Sweden. Malmer \& Wallén (2004) estimated that about 50\% less litter (Sphagnum and vascular plants) was produced in the $20^{\text {th }}$ century compared to the $19^{\text {th }}$ century. A direct comparison with our estimate (20-25\% reduction) is not straight forward since we focus on Sphagnum and single out the effect of $\mathrm{N}$ deposition. In their study, Malmer \& Wallén (2004) acknowledge that $\mathrm{N}$ deposition is a likely important factor causing the decrease of litter from Sphagnum, together with general drier conditions. Although being a single peatland, this gives some quantitative support for our predictions that needs to be scrutinized further. The scarcity of suitable validation data highlights the need of long-term monitoring of processes, such as productivity, instead of only state variables, such as vegetation composition.

Our future scenarios suggest that $\mathrm{N}$ deposition impacts predicted for the period between 19502000 will continue in the 21 st century, becoming more pronounced with climate warming. At the European scale, however, the net N deposition impact on carbon uptake by Sphagnum remains small due to the low peatland cover in high $\mathrm{N}$ deposition regions: ranging between -6 to $-15 \mathrm{~g} \mathrm{C} \mathrm{m}^{-2} \mathrm{yr}^{-1}$ relative to 1900 for the period 1950-2050, depending on $\mathrm{N}$ deposition scenario and climate warming. However, at the peatland scale $\mathrm{N}$ deposition could depress Sphagnum $\mathrm{C}$ uptake up to 50-60 $\mathrm{g} \mathrm{C} \mathrm{m}^{-2} \mathrm{yr}^{-1}$. This is twice as large as recent estimates of annual $\mathrm{C}$ sequestration in northern peatlands based on long-term eddy covariance monitoring (Yu et al. 2011). Assuming 10\% of the Sphagnum production eventually enters long-term storage in the anoxic zone (Rydin \& Jeglum 2013), then long-term C sequestration of Sphagnum would be reduced by roughly $5 \mathrm{~g} \mathrm{C} \mathrm{m}^{-2} \mathrm{yr}^{-1}$ in the most negatively affected peatlands. If this long term decrease in C sequestration by Sphagnum can be offset by increased production of vascular plant litter is highly uncertain as non-woody vascular plant litter is readily decomposed and is less likely to enter into the anoxic zone as peat (Rydin \& Jeglum 2013). Moreover, reduced Sphagnum growth may decrease the self-regulation capacity and resilience of these ecosystems to further disturbances such as changes in climate or land-use.

Regions that would be affected most in the future are SW Sweden, Ireland, England, NW Germany, Netherlands and the Alps. Here the $\mathrm{N}$ deposition rates remain too high to halt negative $\mathrm{N}$ impacts, even in the best-case $\mathrm{N}$ deposition scenario without climate change. This suggests that the oceanic-temperate peatlands in Europe will continue to suffer under the 
predicted $\mathrm{N}$ deposition levels. The area estimated to be affected is likely underestimated in southern Europe because of the many small peatlands which may fulfil the CORINE size criteria. Many of these temperate peatlands are protected nature reserves and may continue to face lower Sphagnum production, invasion of vascular plants (Berendse et al. 2001; Tomassen et al. 2004) and continued losses of DON to groundwater and surface waters (Bragazza \& Limpens 2004).

\section{Prediction uncertainties}

Despite the numerous $\mathrm{N}$ application studies carried out in peatlands, making quantitative estimates remains a challenge. In our study we did not include any uncertainties in climate change (e.g. Ruete et al. 2012) or N deposition scenarios. Instead we explored one model for climate change (A1) and $\mathrm{N}$ deposition (GEA-CLE) and compared them with a constant scenario, including all combinations. Sensitivity analyses showed that uncertainties in these variables did not much affect predictions. Likewise, uncertainty in peatland cover was not of major influence and point predictions were mostly influenced by model parameter uncertainties.

Predictions presented here are associated with considerable uncertainties, reflecting both parameter uncertainty, but also unknown variables affecting the effect of $\mathrm{N}$ deposition. It is reasonable to assume that a large proportion of the random variation among $\mathrm{N}$ application experiments is mostly associated with unknown microhabitat and species-specific responses and factors that could not be included here because of the limited amount of data. For example, different effects of $\mathrm{N}$ form (dry versus wet) and vascular plant cover. We argue that at the peatland scale our average effects are reasonable and realistic, although we should be cautious in our interpretation of the large effects reported (e.g. future Sphagnum production reduction by $50 \%$ in some regions). By using higher temperatures we are making predictions near the limits of model space. Nevertheless, these results suggest that interactions between the effect of $\mathrm{N}$ and climate need to be addressed in future research.

Another potential uncertainty resides in the assumption of our model that short term experiments (here 1-6 years) can be extrapolated over a longer time span. This assumption was supported by time series analyses in Limpens et al. (2011) which did not detect an effect of experiment length on the effect of $\mathrm{N}$ application. Accumulated $\mathrm{N}$ deposition (i.e. total $\mathrm{N}$ load) may, however, be as important as deposition rates since low deposition levels may over 
time reach critical loads. We were unable to predict $\mathrm{N}$ deposition effects for a large part of northern Europe, because $\mathrm{N}$ deposition change is too low to allow reliable modelling. $\mathrm{N}$ experiments in peatlands have so far focused on rather large $\mathrm{N}$ loads, preventing accurate assessment of the impact of a more realistic low, but chronic $\mathrm{N}$ deposition rates. Evidence from other ecosystems, such as forest, suggests that low but chronic $\mathrm{N}$ loads induced by experimental $\mathrm{N}$ fertilization of forests in Sweden, Finland and the USA for a period of about 10- 30 year causes enhanced carbon sequestration by increased tree growth without signs of $\mathrm{N}$ saturation (Högberg et al., 2006; Pregitzer et al. 2007; Hyvönen et al., 2008). However, at elevated $\mathrm{N}$ deposition, $\mathrm{N}$ saturation, occurrence of soil acidification and the elevated incidence of pest and diseases may lead to adverse impacts on forest growth (Magill et al. 2004). These results imply that experiments with high $\mathrm{N}$ loads in forests tend to overestimate adverse impacts as compared to low chronic loads. Our model suggest generally positive effects of low N levels on Sphagnum production, which is supported by the field observations in areas that received low $\mathrm{N}$ deposition $\left(\sim 0.5 \mathrm{~g} \mathrm{~m}^{-2} \mathrm{yr}^{-1}\right)$ during an extensive time period (e.g. 50 years - Gunnarsson et al. 2000, 34 years - Vitt et al. 2003). While intact Sphagnumdominated peatlands show a high resistance to disturbances such as moderate drainage or lowintensity fire, the disruption of keystone species such as Sphagnum may reduce the resilience of peatlands and cascade into disequilibrium or ecosystem change (Luo \& Weng 2011). Nevertheless, in the case of $\mathrm{N}$ deposition, it is also possible that thresholds do not exist, or are below a detection limit, and the ecosystem is changing in a continuous manner (Payne et al. 2013).

\section{Evaluating critical loads}

Overall, our analyses support the critical load range of 0.5 to $1.0 \mathrm{~g} \mathrm{~m}^{-2} \mathrm{yr}^{-1}$ for peatlands (Bobbink \& Hettelingh 2011). The lower bound of that range suggests that negative Ndeposition impacts already occur at a very small increase $\left(0.2-0.3 \mathrm{~g} \mathrm{~m}^{-2} \mathrm{yr}^{-1}\right.$ assuming a preindustrial $\mathrm{N}$ deposition of 0.2-0.3 $\mathrm{g} \mathrm{m}^{-2} \mathrm{yr}^{-1}$ ) of $\mathrm{N}$ deposition. In some areas, Sphagnum production showed reductions at the minimum $\mathrm{N}$ deposition increase that could be reliably modelled in our study $\left(0.4 \mathrm{~g} \mathrm{~m}^{-1} \mathrm{yr}^{-1}\right)$, while in other areas a greater increase of $\mathrm{N}$ deposition (up to $1 \mathrm{~g} \mathrm{~m}^{-1} \mathrm{yr}^{-1}$ ) was needed to achieve a significant production decrease. Overall, our results suggest the current critical load holds for the range of climatic conditions predicted for 2050 .

\section{Conclusions}


513 Our modelling analysis suggests that the negative impact of $\mathrm{N}$ deposition was rather limited

514 throughout the $1900 \mathrm{~s}$, but the negative effects observed in the end of the $20^{\text {th }}$ century (up to

515

516

517

518

519

520

521

522

523

524

525

526

527

528

529

530

531

532

533

534 $25 \%$ production reduction) are likely to continue or even increase in the 21 st century.

Peatland-rich areas in Fennoscandia are, however, less impacted and Sphagnum production may even be temporarily stimulated in some areas. Our results stress the vulnerability of temperate peatlands to $\mathrm{N}$ deposition impacts and highlight the need for more studies on the effect of small but chronic elevations of $\mathrm{N}$ deposition. Furthermore, our results suggest the current critical loads for peatlands are also valid under predicted climate warming.

\section{Acknowledgement}

We are indebted to all co-authors involved in the Limpens et al. 2011 meta-analysis, without them this analysis would not have been possible. We also thank J. M. Waddington and two anonymous reviewers for comments on the manuscript. The study was financially supported by a grant from the Swedish Research Council VR to G. G., while financial support from the FP7 EU framework project Eclaire (grant agreement no 282910) was granted to W.d.V. and M.P.

\section{References}

Belyea, L.R. \& Baird, A.J. (2006) Beyond “the limits to peat bog growth”: cross-scale feedback in peatland development. Ecological Monographs, 76, 299-322.

Berendse, F., van Breemen, N., Rydin, H., Buttler, A., Heijmans, M., Hoosbeek, M.R., Lee, J.A., Mitchell, E., Saarinen, T., Vasander, H. \& Wallén, B. (2001) Raised atmospheric $\mathrm{CO}_{2}$ levels and increased $\mathrm{N}$ deposition cause shifts in plant species composition and production in Sphagnum bogs. Global Change Biology, 7, 591-598.

Bergström, A.-K. \& Jansson, M. (2006) Atmospheric nitrogen deposition has caused nitrogen enrichment and eutrophication of lakes in the northern hemisphere. Global Change Biology, 12, 635-643. 
Bobbink, R. \& Hettelingh, J.-P. (2011) Review and revision of empirical critical loads and dose-response relationships. RIVM Report 680359002, Bilthoven The Netherlands, pp.23-25.

Bossard, M., Feranec, J. \& Ot'ahel', J. (2000) CORINE land cover technical giude Addendum 2000. Technical report, 40. European Environment Agency, Copenhagen. http://terrestrial.eionet.eea.int

Bragazza, L. \& Limpens, J. (2004) Dissolved organic nitrogen dominates in European bogs under increasing atmospheric N deposition. Global Biogeochemical Cycles, 18, GB4018.

Büttner, G. \& Maucha, G. (2006) The thematic accuracy of CORINE Land Cover 2000. Assessment using LUCAS (land use/cover area frame statistical survey). EEA Technical report no.7/2006. Copenhagen, Denmark.

Chapman, S.B. \& Rose, R.J. (1991) Changes in the vegetation at Coom Rigg Moss National Nature Reserve within the period 1958-86. Journal of Applied Ecology, 28, 140-153.

de Vries, W., Reinds, G.J. Gundersen, P. \& Sterba, H. (2006) The impact of nitrogen deposition on carbon sequestration in European forests and forest soils. Global Change Biology, 12, 1151-1173.

de Vries, W. \& Posch, M. (2011) Modelling the impact of nitrogen deposition, climate change and nutrient limitations on tree carbon sequestration in Europe for the period 19002050. Environmental Pollution, 159, 2289-2299.

Dise, N.B. (2009) Peatland response to global change. Science, 326, 810-811.

Freeman, C., Ostle, N. \& Kang, H.J. (2001) An enzymic 'latch' on a global carbon store. Nature, 409, 149.

Galloway, J.N., Aber, J.D., Erisman, J.W., Seitzinger, S.P., Howarth, R.W., Cowling, E.B. \& Cosby, B.J. (2003) The nitrogen cascade. Bioscience, 53, 341-356. 
565 Gerdol, R. (1995) The growth dynamics of Sphagnum based on field measurements in a temperate bog and on laboratory cultures. Journal of Ecology, 83, 431-437.

567

568

569

570

571

572

573

574

575

576

577

578

579

580

581

582

583

584

585

586

587

588

589

Granath, G., Wiedermann, M.M. \& Strengbom, J. (2009) Physiological responses to nitrogen and sulphur addition and raised temperature in Sphagnum balticum. Oecologia, 161, 481-490.

Granath, G., Strengbom, J. \& Rydin, H. (2012) Direct physiological effects of nitrogen on Sphagnum: a greenhouse experiment. Functional Ecology, 26, 353-364.

Gunnarsson, U. (2005) Global patterns of Sphagnum productivity. Journal of Bryology, 27, 267-277.

Gunnarsson, U., Boresö-Bronge, L., Håkan, R. \& Ohlson, M. (2008) Near-zero recent carbon accumulation in a bog with high nitrogen deposition in SW Sweden. Global Change Biology, 14, 2152-2165.

Gunnarsson, U., Sjörs, H. \& Rydin, H. (2000) Diversity and pH changes after 50 years on the boreal mire Skattlösbergs Stormosse, Central Sweden. Journal of Vegetation Science, 11, 277-286.

Hadfield, J.D. (2010) MCMC methods for multi-response generalized linear mixed models: The MCMCglmm R package. Journal of Statistical Software, 33, 1-22.

Heijmans, M.M.P.D., Mauquoy, D., van Geel, B. \& Berendse, F. (2008) Long-term effects of climate change on vegetation and carbon dynamics in peat bogs. Journal of Vegetation Science, 19, 307-320.

Hijmans, R., J. \& van Etten, J. (2012) raster: Geographic data analysis and modeling. R package version 2.1-25.

Högberg, P., Fan, H., Quist, M., Binkley, D., Tamm, C.O., 2006. Tree growth and soil acidification in response to 30 years of experimental nitrogen loading on boreal forest. Global Change Biology, 12, 489-499. 
590

591

592

593

594

595

596

597

598

599

600

601

602

603

604

605

606

607

608

609

610

611

612

613

614

Hyvönen, R., Persson, T., Andersson, S., Olsson, B., Ågren, G.I., Linder, S., 2008. Impact of long-term nitrogen addition on carbon stocks in trees and soils in northern Europe. Biogeochemistry, 89, 121-137.

Johnson, L.C. \& Damman, A.W.H. (1993) Decay and its regulation in Sphagnum peatlands. Advances in Bryology, 5, 249-296.

Kapfer, J., Grytnes, J.-A., Gunnarsson, U. \& Birks, H.J.B. (2011) Fine-scale changes in vegetation composition in a boreal mire over 50 years. Journal of Ecology, 99, 11791189.

Keitt, T.H., Bivand, R., Pebesma, E. \& Rowlingson, B. (2012) rgdal: Bindings for the Geospatial Data Abstraction Library. R package version 0.8-9.

Lamers, L.P.M., Bobbink, R. \& Roelofs, J.G.M. (2000) Natural nitrogen filter fails in polluted raised bogs. Global Change Biology, 6, 583-586.

Limpens, J. \& Berendse, F. (2003) Growth reduction of Sphagnum magellanicum subjected to high nitrogen deposition: the role of amino acid nitrogen concentration. Oecologia, 135, 339-345.

Limpens, J., Berendse, F., Blodau, C., Canadell, J.G., Freeman, C., Holden, J., Roulet, N., H. Rydin H. \& Schaepman-Strub, G. (2008) Peatlands and the carbon cycle: from local processes to global implications - a synthesis. Biogeosciences .5, 1475-1491.

Limpens, J., Granath, G., Aerts, R., Heijmans, M., Sheppard, L., Bragazza, L., Williams, B., Rydin, H., Bubier, J., Moore, T., Rochefort, L., Mitchell, E., Buttler, A., van den Berg, L., Gunnarsson, U., Francez, A.J., Gerdol, R., Thormann, M., Grosvernier, P., Wiedermann, M., Nilsson, M., Hoosbeek, M., Bayley, S., Nordbakken, J.F., Paulissen, M.P.C., Hotes, S., Breeuwer, A., Ilomets, M., Tomassen, H., Leith, I. \& Xu, B. (2012) Glasshouse vs field experiments: do they yield ecologically similar results for assessing $\mathrm{N}$ impacts on peat mosses? The New Phytologist, 195, 408-418. 
Limpens, J., Granath, G., Gunnarsson, U., Aerts, R., Bayley, S., Bragazza, L., Bubier, J., Buttler, A., van den Berg, L., Francez, A.J., Gerdol, R., Grosvernier, P., Heijmans, M., Hoosbeek, M., Hotes, S., Ilomets, M., Leith, I., Mitchell, E., Moore, T., Nilsson, M., Nordbakken, J.F., Rochefort, L., Rydin, H., Sheppard, L., Thormann, M., Wiedermann, M., Williams, B. \& Xu, B. (2011) Climatic modifiers of the response to nitrogen deposition in peat-forming Sphagnum mosses: a meta-analysis. The New Phytologist, 191, 496-507.

Luo, Y. \& Weng, E. (2011) Dynamic disequilibrium of the terrestrial carbon cycle under global change. Trends in Ecology \& Evolution, 26, 96-104.

Magill, A.H., Aber, J.D., Currie, W., Nadelhoffer, K., Martin, M., McDowell, W.H., Melillo, J.M., Steudler, P., 2004. Ecosystem response to 15 years of chronic nitrogen additions at the Harvard Forest LTER, Massachusetts, USA. Forest Ecology and Management, 196, 7-28.

Malmer, N. \& Wallén, B., 2004. Input rates, decay losses and accumulation rates of carbon in bogs during the last millenium: internal processes and environmental changes. Holocene, 14, 111-117.

Malmer, N. \& Wallén, B. (2005) Nitrogen and phosphorus in mire plants: variation during 50 years in relation to supply rate and vegetation type. Oikos, 109, 539-554.

Mitchell, T.D., Carter, T.R., Jones, P.D., Hulme, M. \& New, M. (2004) A comprehensive set of high-resolution grids of monthly climate for Europe and the globe: the observed record (1901-2000) and 16 scenarios (2001-2100). Tyndall Centre for Climate Change Research, Working Paper 55, pp. 25.

Nakićenović, N. \& Swart, R. (2000) Special Report on Emission Scenarios. Intergovernmental Panel on Climate Change, Cambridge University Press, Cambridge. 
Payne, R., Dise, N., Stevens, C., Gowing, D. \& Partners, B. (2013) Impact of nitrogen deposition at the species level. Proceedings of the National Academy of Sciences of the United States of America, 110, 984-987.

Pregitzer, K.S., Burton, A.J., Zak, D.R., Talhelm, A.F., 2007. Simulated chronic nitrogen deposition increases carbon storage in Northern Temperate forests. Global Change Biology, 14, 1-12.

Raupach, M.R., Marland, G., Ciais, P., Le Quéré, C., Canadell, J.G., Klepper, G. \& Field, C.B. (2007) Global and regional drivers of accelerating CO2 emissions. Proceedings of the National Academy of Sciences of the United States of America, 104, 1028810293

Roulet, N.T., Lafleur, P.M., Richard, P.J.H., Moore, T.R., Humphreys, E.R. \& Bubier, J. (2007) Contemporary carbon balance and late Holocene carbon accumulation in a northern peatland. Global Change Biology, 13, 397-411.

Ruete, A., Yang, W., Bärring, L., Stenseth, N. \& Snäll, T. (2012) Disentangling effects of uncertainties on population projections: climate change impact on an epixylic bryophyte. Proceedings. Biological sciences / The Royal Society, 279, 3098-3105.

Rydin, H. \& Jeglum, J.K. (2013) The Biology of Peatlands. $2^{\text {nd }}$ edn, Oxford University Press, New York.

Simpson, D., Benedictow, A., Berge, H., Bergström, R., Emberson, L.D., Fagerli, H., Flechard, C.R., Hayman, G.D., Gauss, M., Jonson, J.E., Jenkin, M.E., Nyiri, A., Richter, C., Semeena, V.S., Tsyro, S., Tuovinen, J.-P., Valdebenito, A., Wind, P., (2012) The EMEP MSC-W chemical transport model - technical description. Atmospheric Chemistry and Physics 12, 7825-7865. 
662

663

664

665

666

667

668

669

670

671

672

673

674

675

676

677

678

679

680

681

682

683

Tomassen, H.B.M., Smolders, A.J.P., Limpens, J., Lamers, L.P.M. \& Roelofs, J.G.M. (2004) Expansion of invasive species on ombrotrophic bogs: desiccation or high $\mathrm{N}$ deposition. Journal of Applied Ecology, 41, 139-150.

Turunen, J., Roulet, N.T., Moore, T.R. \& Richard, P.J.H. (2004) Nitrogen deposition and increased carbon accumulation in ombrotrophic peatlands in eastern Canada. Global Biogeochemical Cycles, 18, GB3002.

van Breemen, N. (1995) How Sphagnum bogs down other plants. Trends in Ecology \& Evolution, 10, 270-275.

Vitt, D.H. (1990) Growth and production dynamics of boreal mosses over climatic, chemical and topographic gradients. Botanical Journal of the Linnean Society, 104, 35-59.

Vitt, D.H., Wieder, K., Halsey, L.A. \& Turetsky, M., (2003) Response of Sphagnum fuscum to nitrogen deposition: A case study of ombrogenous peatlands in Alberta, Canada. The Bryologist, 106, 235-245.

Wallén, B. (1992) Methods for studying below-ground production in mire ecosystems. Suo, 43, 155-162.

Wieder, R.K., Vitt, D.H., Burke-Scoll, M., Scott, K.D., House, M. \& Vile, M.A., 2010. Nitrogen and sulphur deposition and the growth of Sphagnum fuscum in bogs of the Athabasca Oil Sands Region, Alberta. Journal of limnology, 69, 161-170.

Yu, Z., Beilman, D.W., Frolking, S., MacDonald, G.M., Roulet, N.T., Camill, P. \& Charman, D.J. (2011) Peatlands and their role in the global carbon cycle. Eos, Transactions American Geophysical Union, 92, 97-98. 
684 Table 1. Results of the Hierarchical Bayes Linear Models (HBLM) with $\log _{\mathrm{e}}$ response ratio.

685 Negative coefficients indicate that an increase in the predictor depresses the response of

686 Sphagnum to adding N. Categorical levels are compared to the intercept which is set to

687 without $\mathrm{P}$ addition and without vascular plants. Upper and lower 95\% credible intervals are

688 given. Residual heterogeneity represents between study variation not explained by predictors.

689 Of the total between study variation, $51 \%$ was explained by the included predictors. $\mathrm{N}=107$.

\begin{tabular}{lccc} 
& coefficients & lower-95\% & upper-95\% \\
\hline & & & \\
Intercept & 1.491 & 0.847 & 2.124 \\
Nitrogen $(\mathrm{N})$ application rate & -0.032 & -0.056 & -0.009 \\
Background N deposition & -0.200 & -0.393 & -0.009 \\
Mean July temperature & -0.049 & -0.083 & -0.014 \\
Mean annual precipitation & -0.000372 & -0.000741 & -0.000013 \\
Presence of vascular plants & -0.377 & -0.585 & -0.181 \\
Phosphorus application & 0.225 & 0.023 & 0.432 \\
\hline & & & \\
Residual heterogeneity $\left(\tau^{2}\right)$ & 0.062 & 0.032 & 0.097 \\
\hline
\end{tabular}

690

691

692

693

694

695

696

697

698

699

700

701

702

703

704

705

706

707 
Table 2. Summary statistics of model predictions at the European scale (see Fig.1 for coverage). CLE $\mathrm{N}$ refers to the current legislation $\mathrm{N}$ emission scenario (GEA-CLE, here called CLE N) and A1 clim change to the A1 climate scenario. Constant $\mathrm{N}$ keeps $\mathrm{N}$ deposition at the mean of 2000-2010 and constant climate uses the mean of 1961-1990. Average effect of $\mathrm{N}$ deposition on Sphagnum production and Sphagnum C balance of Sphagnum-dominated peatlands are calculated as weighted means using peatland cover in grid cells as weights. Area indicates total peatland area where Sphagnum is estimated to have been, or to be, affected negatively or positively. The $1^{\text {st }}$ and $99^{\text {th }}$ percentiles are given to show the range of the grid cell predictions.

\begin{tabular}{|c|c|c|c|c|c|}
\hline Period & Scenario & $\begin{array}{c}\text { Average effect on } \\
\text { production }\left(1^{\text {st }}, 99^{\text {th }} \% \text { ile }\right) \\
(\% \text { change })\end{array}$ & $\begin{array}{c}\text { Average effect on } \\
\text { C balance }(1 \mathrm{st}, 99 \text { th } \% \text { ile }) \\
\left(\mathrm{g} \mathrm{m}^{-2} \mathrm{yr}^{-1}\right)\end{array}$ & $\begin{array}{c}\text { Area } \\
(\mathrm{mil} . \text { ha })\end{array}$ \\
\hline & & & neg & pos \\
\hline $1900-1950$ & - & - & - & - \\
\hline $1950-2000$ & $-6(-46,9)$ & $-6(-46,9)$ & 0.84 & 0.36 \\
\hline $2000-2050$ CLE N, A1 Clim Change & $-12(-65,16)$ & $-12(-65,16)$ & 1.11 & 0.44 \\
\hline & CLE N, Constant climate & $-5(-58,25)$ & $-5(-58,25)$ & 0.92 & 0.63 \\
\hline & Constant N, A1 Clim Change & $-15(-52,0)$ & $-15(-52,1)$ & 1.54 & 0.05 \\
\hline & Constant N and Constant climate & $-8(-49,11)$ & $-8(-49,11)$ & 1.22 & 0.37 \\
\hline
\end{tabular}


A) $\mathrm{N}$ deposition 1900

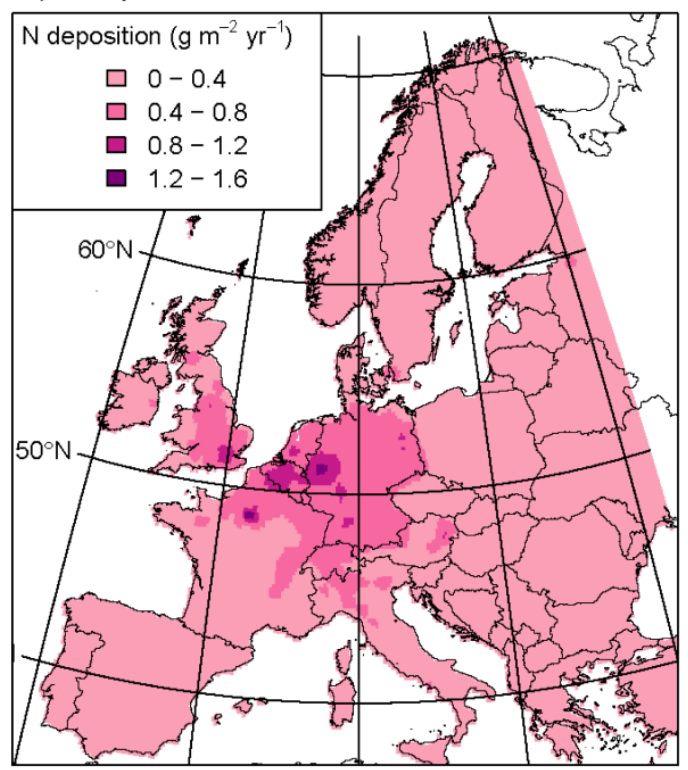

C) Mean change in $\mathrm{N}$ deposition $1950-2000$ vs $1900-1950$

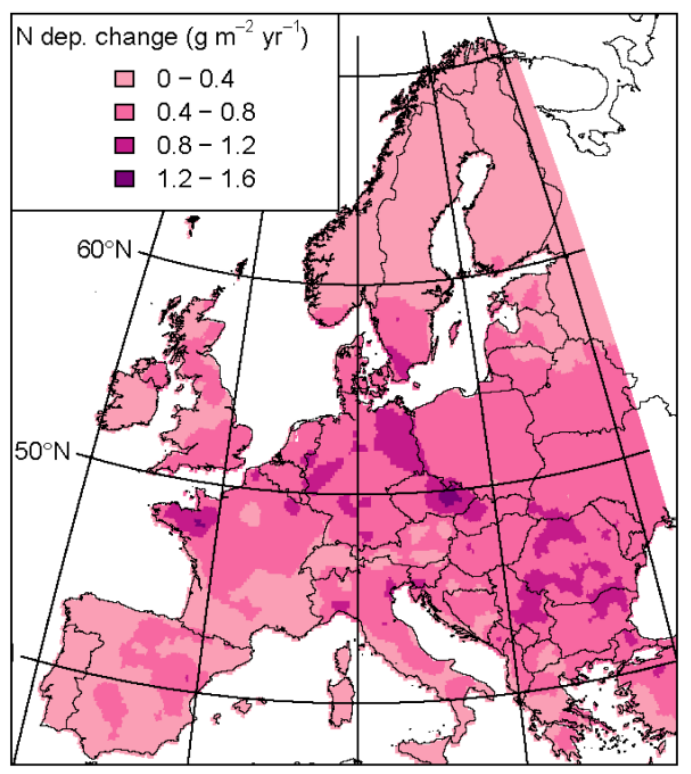

B) Mean change in $\mathrm{N}$ deposition $1900-1950$ vs 1900

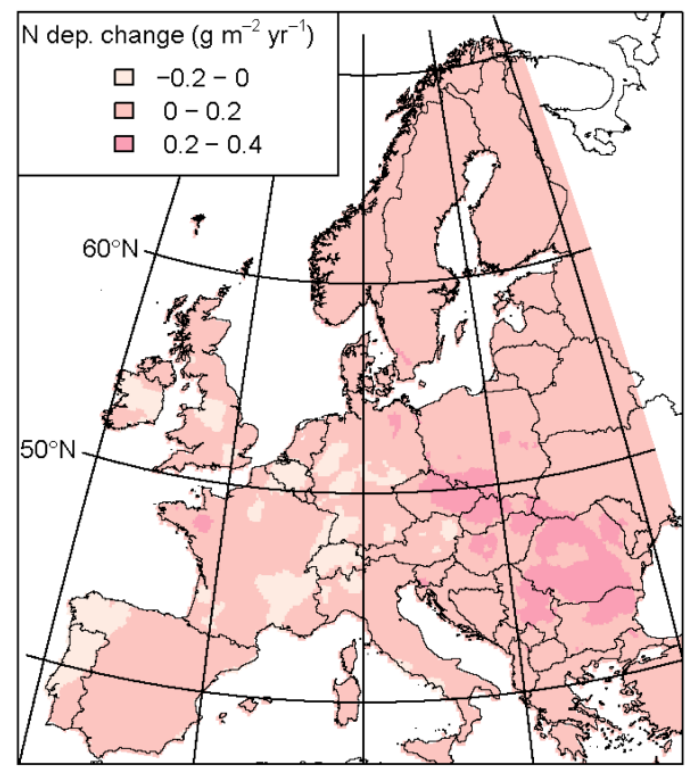

D) Mean change in $\mathrm{N}$ deposition 2000-2050 (CLE scenario) vs 1950-2000

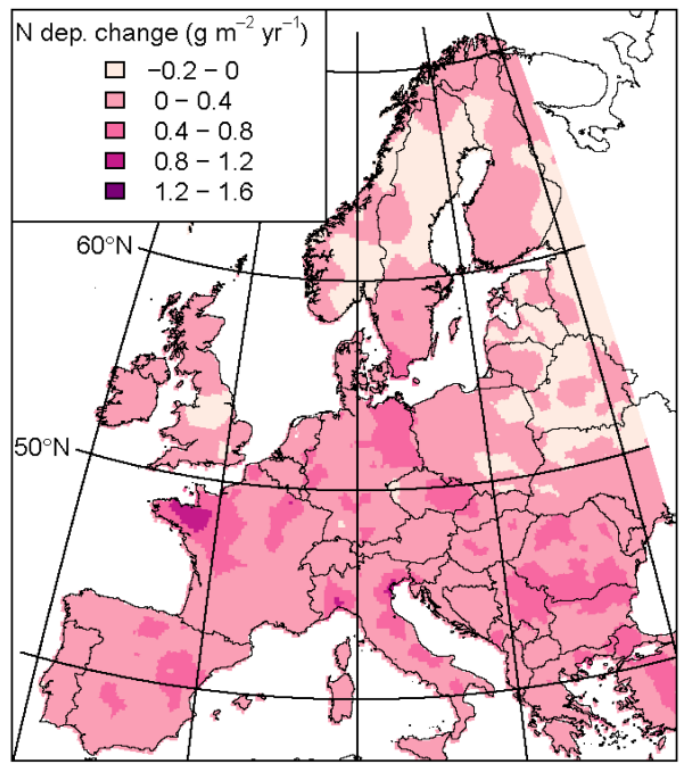

733 Fig 1. (A) Modelled nitrogen (N) deposition over Europe in the year 1900 and changes in N 734 deposition over three time periods; (B) mean 1900-1950 compared to 1900, (C) mean 19502000 compared to the 1900-1950 mean, and (D), mean 2000-2050, compared to the 19502000 mean. Predictions for 2000-2050 (C) are based on the GEA-CLE deposition scenario. 


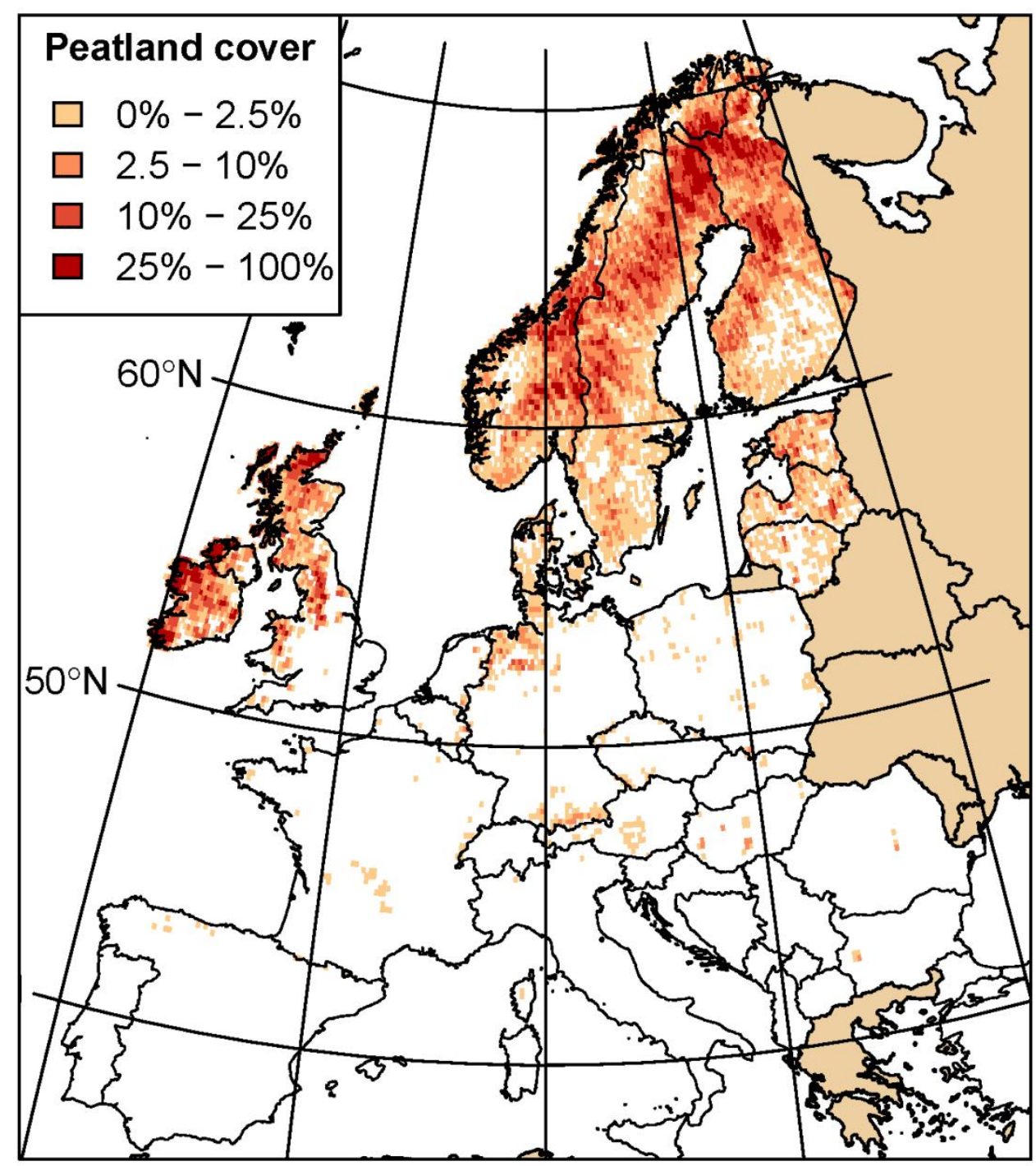

738 Fig. 2. Map showing the abundance (proportion of total land area) and distribution of open to semi-open Sphagnum-dominated peatlands in Europe. Data are based on the JRC forest map and the CORINE 2006 land cover map. The light brown colour indicates countries without 741 data. 
A) $\mathrm{N}$ deposition effect $1950-2000$

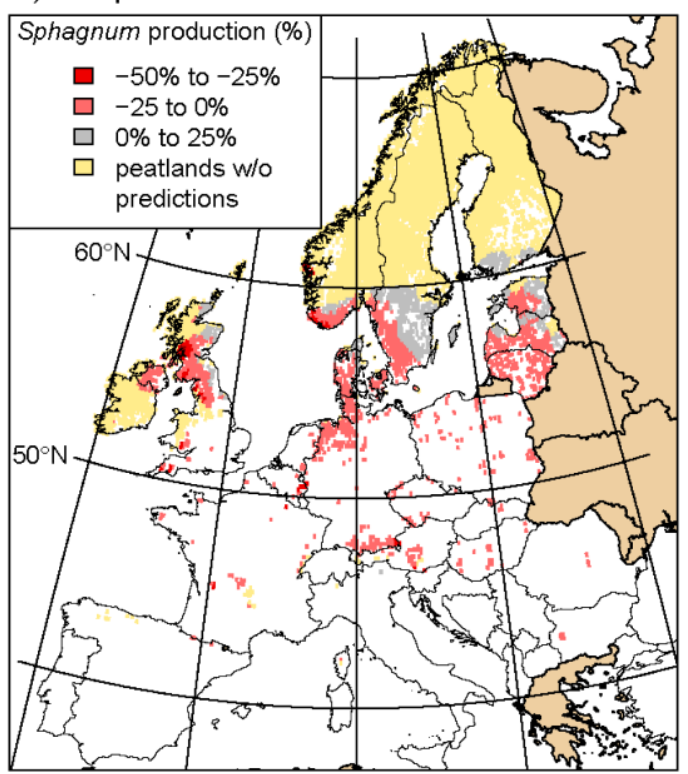

C) $\mathrm{N}$ deposition effect $2000-2050$ (constant N, A1 climate change)

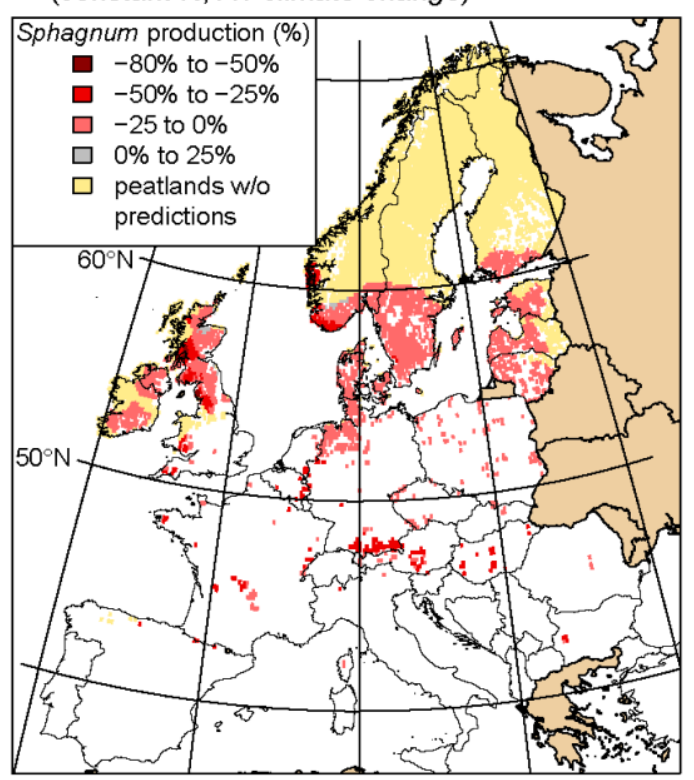

B) $\mathrm{N}$ deposition effect $2000-2050$

(CLE N scenario, A1 climate change)

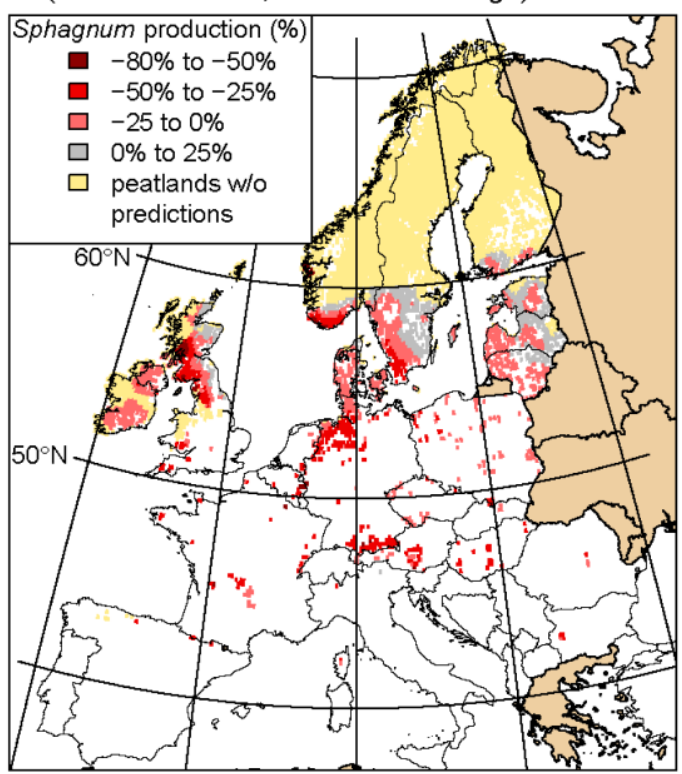

D) $\mathrm{N}$ deposition effect $2000-2050$ (constant $\mathrm{N}$, constant climate)

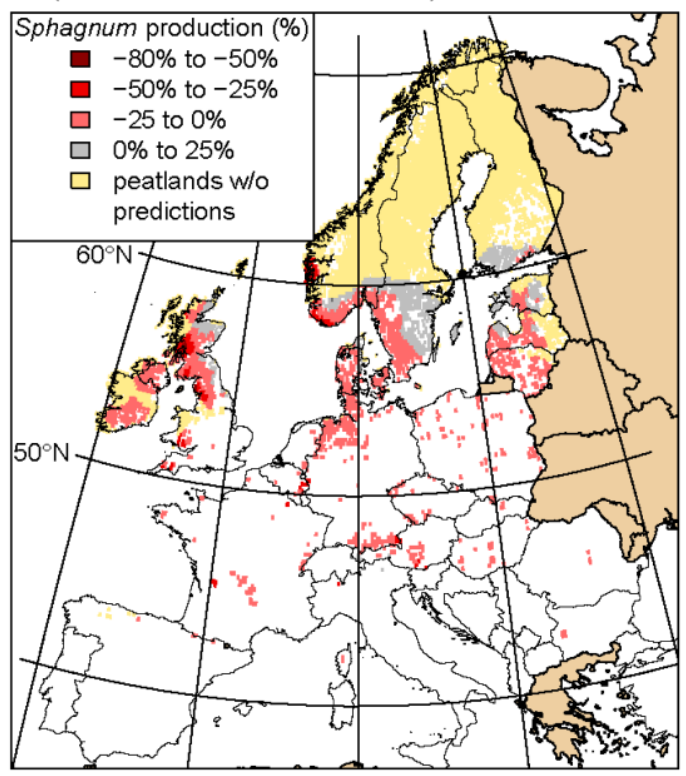

Fig 3. Effects of $\mathrm{N}$ deposition on Sphagnum production presented as percentage change relative to 1900. Annual mean effect between (a) 1950 to 2000, (b) 2000 to 2050 under a current legislation emission scenario (GEA-CLE, here called CLE N scenario) and the A1 climate change scenario, (c) 2000 to 2050 assuming constant $\mathrm{N}$ deposition (mean of 20002010) and climate change scenarioA1, (d) 2000 to 2050 assuming constant $\mathrm{N}$ deposition and constant climate (1961-1990 average). Only open to semi-open Sphagnum dominated peatlands were modelled. Yellow illustrates areas where $\mathrm{N}$ deposition were too low $(<0.4 \mathrm{~g}$ 
$751 \mathrm{~m}^{-2} \mathrm{yr}^{-1}$ increase since 1900) to make reliable predictions. Light brown colour indicates 752 countries without data on peatland distribution.

753

754

755

756

757

758

759

760

761

762

763

764

765

766

767

768

769

770

771

772

773

774

775

776

777 


\section{Supporting Information}

779 Appendix S1. Figures illustrating the uncertainties of some of the predictions

Fig. S1. Prediction uncertainties - 90\% credible intervals

A) Lower $90 \%$ prediction interval (1950-2000)

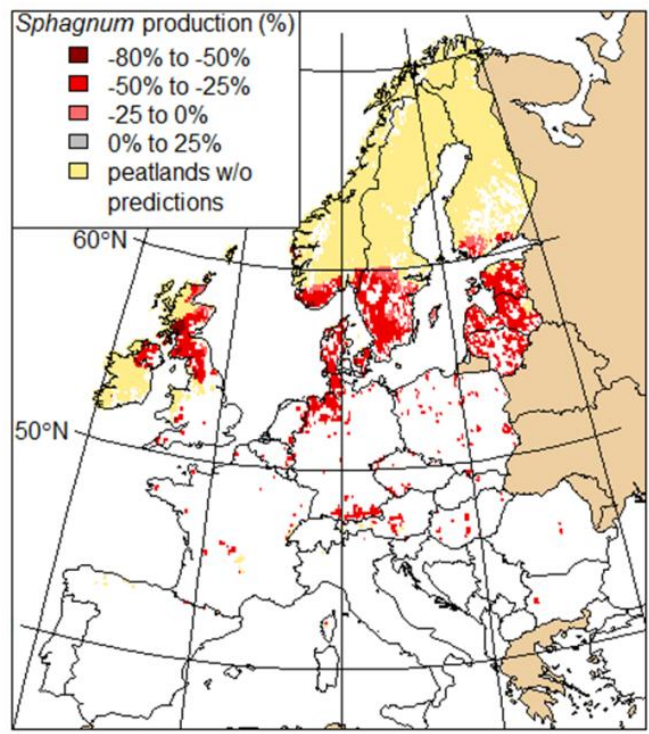

C) Lower $90 \%$ prediction interval (2000-2050, Constant N, A1 Clim change)

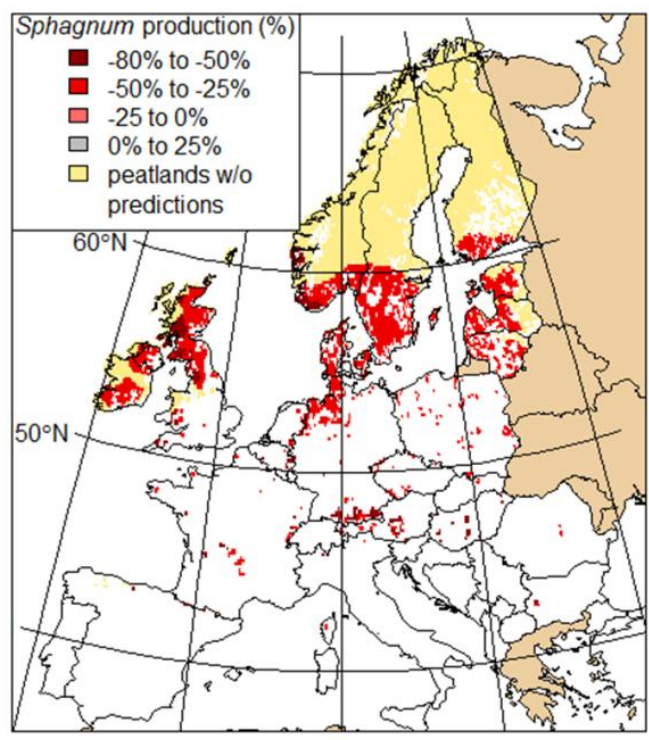

B) Upper $90 \%$ prediction interval (1950-2000)

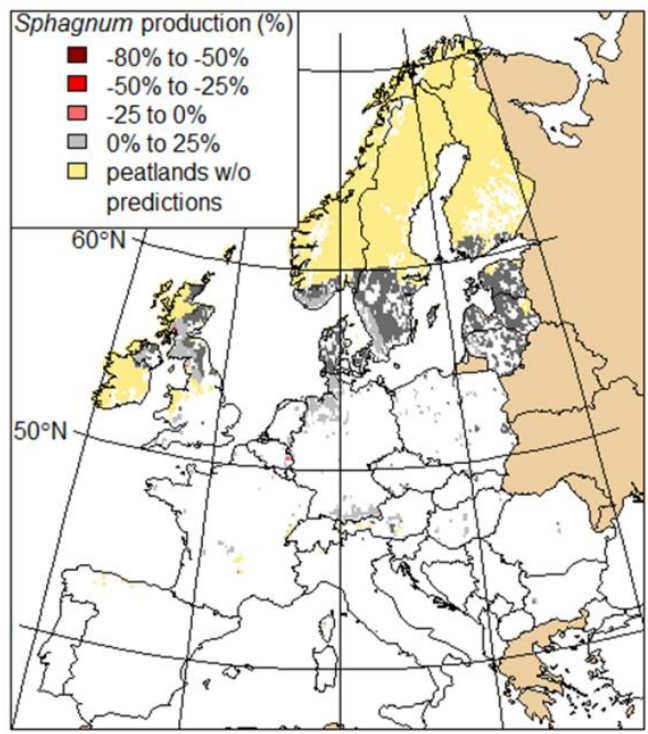

D) Upper $90 \%$ prediction interval (2000-2050, Constant N, A1 Clim change)

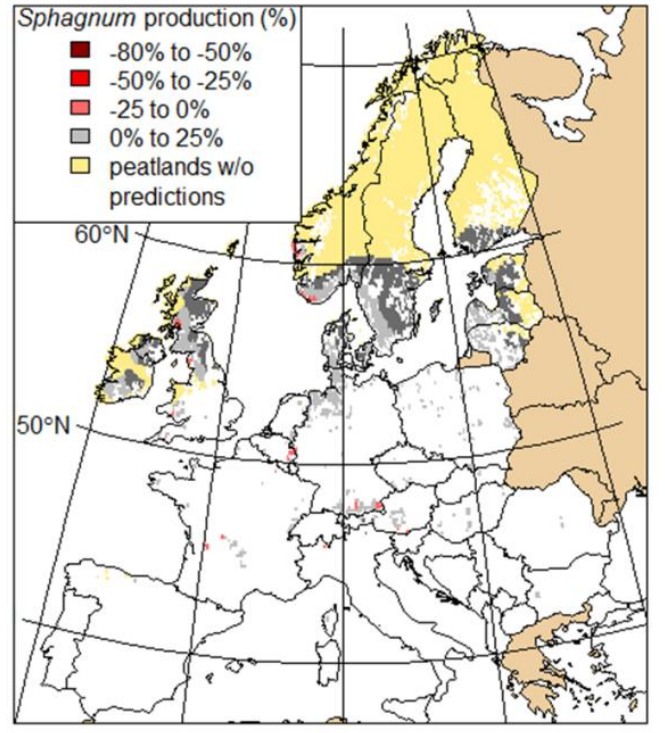

Fig. S1. Examples of prediction uncertainties (90\% credible intervals) for two models, a-b) 
Fig. S2. Prediction uncertainties - 50\% credible intervals

A) Lower $50 \%$ prediction interval (1950-2000)

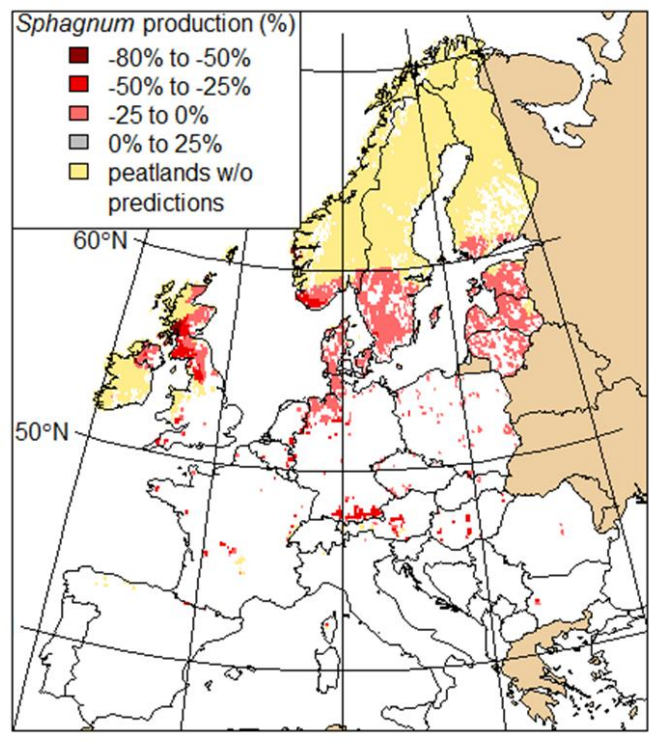

C) Lower $50 \%$ prediction interval (2000-2050, Constant N, A1 Clim change)

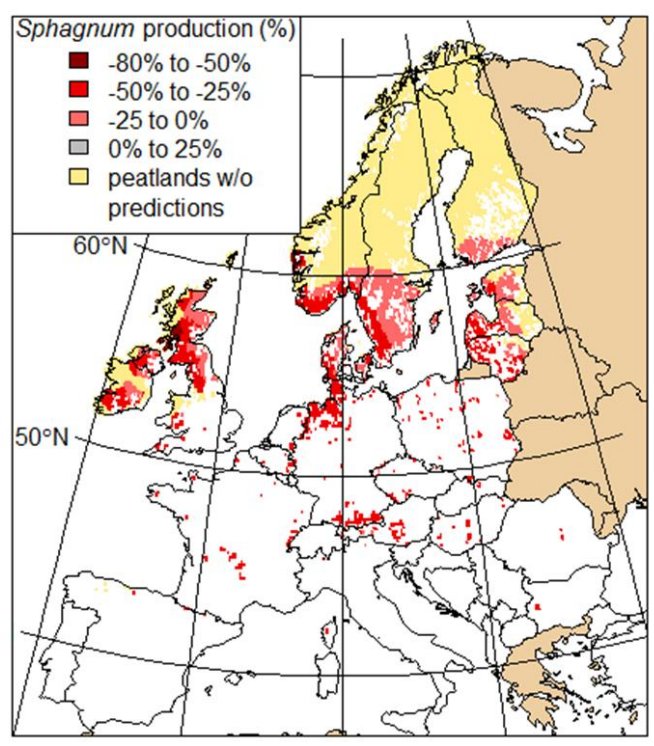

B) Upper 50\% prediction interval (1950-2000)

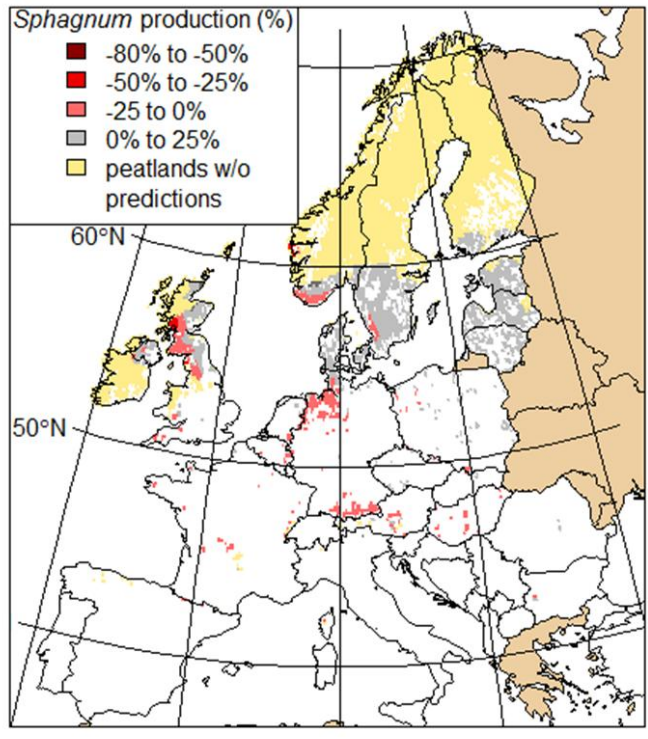

D) Upper $50 \%$ prediction interval (2000-2050, Constant N, A1 Clim change)

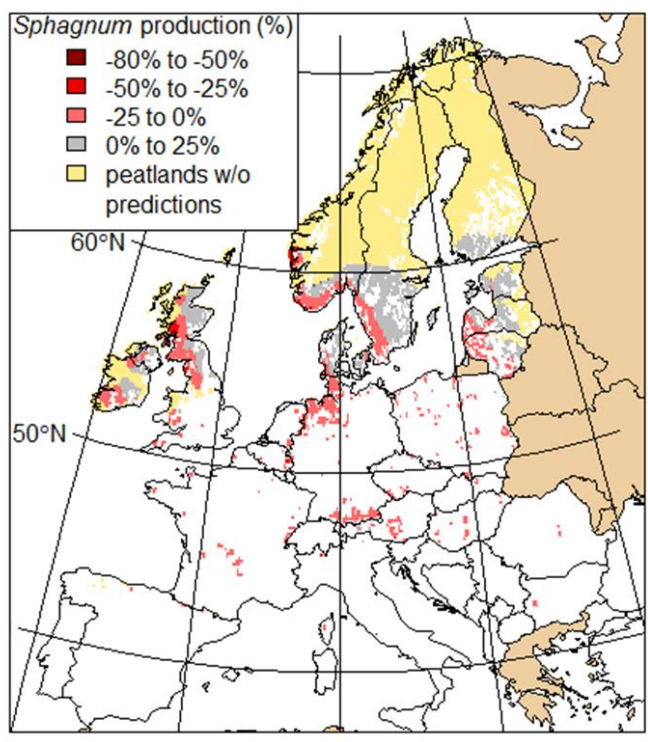

Fig. S2. Examples of prediction uncertainties (50\% credible intervals) for two models, a-b) 